\title{
Eğitim, Sağlık, Ekonomi ve Bireysel Özgürlüklerin Yönetişime Etkisi
}

\author{
Yusuf SOYUPEK*
}

\begin{abstract}
$\ddot{O} Z$
1980 'li yıllardan sonra yoğun bir şekilde kullanılan yönetişim kavramı, sosyal bilimlerin en gözde kavramlarından biri haline gelmiştir. Özellikle Dünya Bankası'nın gelişmekte olan ülkeler için hazırladı̆̆ raporlarla birlikte kullanımı ve bilinirliği artan yönetişim kamu yönetiminde de pek çok çalı̧̧maya konu olmuştur. Yönetişim kavramı, yönetişimin tanımı, çeşitleri, gelişimi, ilkeleri, teorik ve düşünsel temelleri bu çalışmaların ana çerçevesini oluşturmuştur.

Bu çalışmada alanda daha önce yapılmayan bir analiz ortaya koyularak eğitim, sağhlk, ekonomi ve bireysel özgürlüklerin yönetişime bir etkisinin olup olmadı̆̆ araştırılmaktadır. Bu çerçevede uluslararası indekslerden elde edilen nicel veriler ile ülkelerin eğitim, sağllk, ekonomi ve bireysel özgürlük skorları ile yönetişim skorları arasındaki ilişki test edilmiştir. Yapılan analiz sonucunda yönetişim kalitesini artırmanın ve yönetişim anlayışını hâkim kılmanın yolunun; ülkelerin sağllk, ekonomi ve özellikle bireysel özgürlük seviyelerini artırmaktan geçtiği sonucuna varılmıştır.
\end{abstract}

Anahtar Kelimeler: Yönetişim, Eğitim, Sağllk, Ekonomi, Bireysel Özgürlük

JEL Sinıflandırma: G34, H75, E26

\section{The Impact of Education, Health, Economy and Personal Freedom on Governance}

\section{ABSTRACT}

After 1980's the governance concept used intensively has become one of the most popular concepts of social sciences. It has also been the subject of many studies in public administration especially with the report prepared by the World Bank for developing countries because of increase of the use and awareness. The concept of governance, governance definition, types, development, principles, theoretical and philosophical basis are the main framework of this study.

In this study, we are researching the relationship between governance and education, health, economy and personal freedom. In this context, with data obtained from international index, the relationship between education, health, economy, personal freedom scores of countries and its governance scores were tested. As a result of the study, the relation between governance and education are absent, health, economy and personal freedom have been identified a positive relation with the governance.

Keywords: Governance, education, health, economy, personal freedom

JEL Classification: G34, H75, E26

\section{GíRiş}

Yönetişim, sosyal bilimlerin yaşadığı paradigmatik krizlerin etkisiyle ortaya çıkan ve mevcut yaklaşımların söz konusu krizlere cevap verememesi nedeniyle gelişen bir kavramdır. Yönetişim, 20. yüzyılın son çeyreğinden itibaren, sosyal bilimlerde iktisattan uluslararası ilişkilere, idari bilimlerden kamu

\footnotetext{
*Yrd. Doç. Dr, Çankırı Karatekin Üniversitesi İktisadi ve İdari Bilimler Fakültesi, yusufsoyupek@gmail.com
} 
yönetimine kadar birçok alanda kullanılan popüler ve joker bir kavram haline gelmiştir. Geleneksel kamu yönetimi anlayışının giderek etkisiz ve yetersiz kalmasıyla yönetişim yaklaşımı geliştirilerek kullanılmaya ve özellikle uluslararası kuruluşlar tarafından kalkınmanın temel faktörü olarak sunulmaya başlanmıştır.

Yönetişim kavramının ortaya çıkıp yaygın bir şekilde kullanılmasında Dünya Bankası'nın gelişmekte olan ülkeler için hazırladığı raporlar önemli yer tutmaktadır. Bu raporlarda yönetişim; ekonomik kalkınma ve refah için, hukukun üstünlügü ve demokrasiyle bağlantılı olarak kullanılmıştır. Bundan sonra kavram sosyal bilimlerde birçok alanda yaygın bir şekilde kullanılmış ve sayısız çalışmaya konu olmuştur.

$\mathrm{Bu}$ çalışmada eğitim, sağlık, ekonomi ve bireysel özgürlüklerin yönetişim ile ilgisi açıklanmaya çalışılmıştır. Çalışmanın amacı eğitim, sağlık, ekonomi ve bireysel özgürlüklerin yönetişim üzerindeki etkisini ortaya koymaktır. Çalışmada nitel ve nicel veriler kullanılarak betimsel ve çıkartımsal bir araştırma ortaya konulmuştur. Nitel veriler, akademik yayınlar ve uluslararası kuruluş raporlarından, nicel veriler ise Legatum Prosperity Index (LPI)-Legatum Refah İndeksi adlı veri bankasından elde edilmiştir. Eğitim, sağlık, ekonomi ve bireysel özgürlükler ile yönetişimin arasındaki ilişkiyi istatistiksel olarak analiz etmek için birçok test uygulanmıştır.

Çalışmada öncelikle yönetişim ile ilgili literatür çalışması yapılmıştır. Bu çerçevede yönetişim kavramı, kavramın etimolojik kökeni, ortaya çıkışı, tanımı ve gelişimi ele alınmıştır. 1980'li yıllarda yönetim bilimlerinde yaşanan krize çözüm bulma kaygısıyla ortaya atılan diğer yönetim yaklaşımları ile yönetişim arasındaki ilişkinin ne olduğu anlaşılmadan yönetişimi açılamanın imkânsız olduğu gerçeğinden hareketle yönetişim ile geleneksel kamu yönetimi ve yeni kamu yönetimi yaklaşımları karşılaştırılmıştır. Son olarak yönetişimin düşünsel ve teorik temelleri de vurgulandıktan sonra ikincil veri analizine dayanan istatiksel analiz yapılarak eğitim, sağlık, ekonomi ve bireysel özgürlüklerin yönetişime etkisi tartışılmışıtır.

\section{I.KAVRAM OLARAK YÖNETIŞSIM}

Yönetişim kavramının kökenlerine yönelik olarak literatürde farklı bilgiler bulunmaktadır. Bazı yazarlar kavramın ilk kez 14. yüzyılda Fransa'da "hükümet merkezi" (seat of government) anlamında kullanıldığını ifade ederken (Löffler, 2003) bazı yazarlar da kavramın 16. veya daha bilinen şekliyle 18. yüzyılda filozofların sivil topluma saygılı bir hükümet beklentilerinin ifadesi olarak kullanıldığını belirtmektedirler (Gaudin, 1998).

Kavramın Latince dümen tutmak, yönetmek anlamlarına gelen "gubernare" fiilinden (Lowndes, 2006; Hughes, 2012) veya Yunanca dümen tutmak, kılavuzluk yapmak anlamına karşılık gelen "kubernân" fiilinden (Çukurçayır ve ark. 2010; Lowndes, 2006; Hughes, 2012) geldiği ifade edilmektedir. Yönetişim kavramı, literatürde ilk kez Sidney Low tarafından 1904 yılında yazılan "The Governance of England" isimli eserde yönetimin eş anlamlısı olarak kullanılmıştır (Rhodes, 1996). Kavrama bu şekilde eski Yunanca veya 
Latinceden köken bulma çalışmaları eleştirilmiş ve aslında yönetişimin yeni bir şey ifade etmediği, sadece yönetim kavramı ile ifade edilemeyen veya daha açık bir ifadeyle alıcı bulamayan yeni düşüncelerin bu kavramla birlikte ifade edildiği belirtilmiştir (Güler, 2003). Kavrama tıpkı yeni kamu yönetimi kavramında olduğu gibi “yeni şişedeki eski şarap" metaforu yakıştırılmıştır (Gültekin, 2011).

Yönetişim kavramı bazı yazarlar tarafindan "göçmen kavram" (concept migrant) olarak tanımlamaktadır. Yönetişim kavramı 1980'li yıllardan sonra sosyal bilimlerde birçok alanda kullanılmaya başlandı. İktisadi bilimlerde, ekonomik faaliyetlerin koordinasyonunu sağlayan mekanizmaları formüle etmek için, uluslararası ilişkilerde gitgide parçalanan uluslararası toplumda yeni organizasyon şekillerini belirtmek için, siyaset biliminde devletin yanında diğer aktörlerin ortaya çıkışını teorileştirmek için, idari bilimlerde özellikle kentsel yönetişim aracılığıyla kentlerin yeni yönetiminin karmaşıklığını ortaya koymak için kullanıldı. Buna karşılık, yönetişim kavramı, hukuk bilimlerinde hukuki tekniklerin kullanılma şartlarındaki dönüşümleri göz önünde bulundurmak için kullanılmadı (Chevallier, 2003).

Yönetişim kavramının birçok alanda kullanılmasının ardından, kavram sosyal bilimlerin hem popüler hem de joker kavramı haline geldi (Jessop, 1998). Kavramın daha fazla bilinir ve kullanılır olmasında Dünya Bankası tarafından 1989 yılında hazırlanan bir rapor önemli rol oynamıştır. Dünya Bankası söz konusu raporda yönetişim kavramını, ekonomik kalkınma ve refah için, hukukun üstünlüğü ve demokrasiyle bağlantılı olarak kullandı. Kavram bu rapordan sonra birçok uluslararası kurum ve kuruluş tarafından kullanılmaya başlanmıştır. Kavramın ortaya çıkmasının sebeplerinden biri olarak uluslararası kuruluşların etkinliğinin artmasıyla birlikte ulus devletin müdahale alanının sınırlandırılması, özel sektörün kamu hizmetleri vasıtasıyla kamu sektörüne yaklaşması ve neticede ortaya çıkan çoklu aktörler arasında işbirliği ve koordinasyon gibi etkenler gösterilmektedir (Rhodes, 1996).

Yönetişim kavramını yaygın olarak kullanan kurumlar arasında Avrupa Birliği (AB), Uluslararası Para Fonu (IMF), Ekonomik Kalkınma ve İşbirliği Örgütü (OECD) gibi kurumlar vardır. $A B$, yönetişimi sadece gelişmekte olan ülkeler için önerdiği bir kavram olarak değil, 2000'li y1llarda tüm üye ülkeler için reform çalışmalarının 4 önemli amaçlarından biri olarak görmüştür. $B u$ amaçla $A B$ Komisyonu iyi yönetişimin ilkelerini belirleyen ve $A B$ kurumlarında değişimi, üye ülkelerle ilişkisini ve diğer topluluklarla ilişkisini tanımlayan "Yönetişim Üzerine Beyaz Kitap" hazırlamıştır (Löffler, 2003, Kayalıdere, 2004).

Dünya Bankası'nın 1989 yılındaki raporunda Afrika'da yaşanan kalkınma sorunlarının temel sebebini yönetişim krizi olarak belirtmesi dikkatleri bu kavrama çekmiştir. Yönetim (government) kelimesi ile eşanlamlı olarak kullanılan yönetişim kavramı bu raporda; sistemik, siyasi ve idari olmak üzere üç farklı boyutta tanımlanmıştır. Öncelikle sistem olarak tanımlanan yönetişim; yönetimden daha geniş anlamda, siyasal ve ekonomik iktidarın bölüşülmesi anlamında kullanılmıştır. İkinci olarak demokratik rejime dayanan siyasal rejim tanımlanması 
amacıyla kullanılmıştır. Üçüncü ve son olarak yönetişim; etkin, bağımsız ve hesap verebilen bir kamu yönetimi yapısı olarak tanımlanmıştır (Leftwich, 1994).

\section{A. Yönetişimin Tanımı}

Yönetişim literatüründe de sosyal bilimlerin diğer konularında olduğu gibi bir tanım bolluğu ve dağınıklığı söz konusudur (Stoker, 1998). Yönetişimin bugüne değin hem kurumlar hem de kişiler tarafından pek çok tanımı yapılmıştır. Kamu yönetimi sözlüğünde yönetişim; "bir toplumsal-politik sistemdeki ilgili bütün aktörlerin ortak çabalarıyla elde edilen sonuçların oluşturduğu yapı ya da düzen" olarak tanımlanmaktadır (TODAİE, 1998).

Dünya Bankasının tanımında ise bir ülkenin kaynaklarının etkin bir şekilde kullanılması için hesap verebilirlik, şeffaflık, sivil toplumun kamu politikalarına etkin bir şekilde katılımı, hukukun üstünlüğü ve bağımsız yarg1 gibi ilkelerden oluşan bir süreç olarak tanımlanmıştır. Dünya Bankası 1992 yılındaki tanımında ise yönetişimi, "sağlıklı kalkınma yönetimi" ile eşanlamlı olarak tanımlamıştır.

AB'nin kurucu anlaşmalarında yönetişim, ekonomik büyüme ve yoksulluğun ortadan kaldırılması birbiriyle bağlantılı konular olarak ele alınmaktadır. Birleşmiş Milletler (BM)'nin “Bin Y1l Bildirgesi”nde de kalkınma ve yoksullukla mücadelede yönetişimin en önemli başarı faktörlerinden biri olduğu vurgulanmaktadır (Çukurçayır ve ark, 2010).

Yönetişim, toplumu yönlendirmek ve yönetmek konusunda sorumluluğun devletten sivil topluma kaydığını göstermektedir. Dolayısıyla artık karar alma, uygulama ve politika belirleme süreçlerinde çok aktörlü bir yapı oluşmaya başlamaktadır (Eryılmaz, 2012).

Yönetişim kavramının tanımlarında dikkat çeken temel nokta, yönetişimin katılımcı ve çok aktörlü bir süreç olduğudur (Özeren ve Temizel 2004). Çağdaş bir yönetim yaklaşımı olarak ele alınan yönetişim; kamu kesimi, özel sektör, sivil toplum kuruluşları gibi farklı aktörlerin bir araya gelerek ortak amaçlar çerçevesinde çoğulcu, katılımc1 ve daha demokratik bir yönetim anlayışı ve yöntemi geliştirmesi temeline dayanmaktadır. Bazı açılardan yönetişim, devletin sınırlarının daraltılması, devletin piyasaya daha az müdahale etmesi, devlet dışı aktörlerin etkilerinin ve katılımlarının artması anlamında kullanıldığı da belirtilebilir.

Literatürde yazarlar da yönetişim kavramını farklı şekilde kullanmışlardır. Rhodes, yönetişim kavramının altı farklı kullanım alanı olduğunu belirterek bunları; minimal devlet, kurumsal yönetişim, yeni kamu işletmeciliği, iyi yönetişim, sosyo-sibernetik sistem ve kendiliğinden organize olan ağlar olarak sıralamıştır (Rhodes, 1996, Ergen, 2012). Yönetişimin farklı tanımlarının üzerinde buluştuğu ortak noktalar; özel sektör ile kamu sektörünün sınırlarının muğlaklaşması, karar alma süreçlerine birden fazla aktörün katılması, yönetimde açıklığın ve şeffaflığın sağlanması olarak belirtilebilir.

Yönetişimin farklı kurumsal ve toplumsal yapıda karar alma sürecinde aktörler arasında işbirliğini açıklayan üç tür anlamı üzerinde de durulmuştur. Buna göre: Kurumsal Yönetişim (Corporate Governance): Şirketteki farklı 
güçler/aktörler arasında etkileşime dayanan yeni bir yönetim anlayışı kurmayı amaçlar. İyi Yönetişim (Good Governance): Özellikle uluslararası kuruluşlar tarafindan kalkınmanın en önemli gücü olarak sayılır ve kurumlarının reforme edilmesinin en önemli aracı olarak kabul edilir. Küresel Yönetişim (Global Governance): Uluslararası toplumun yeni bir regülasyon ve entegrasyon modeli kurmayı amaçlar (Chevallier, 2003).

Yönetişim kavramı 18. yüzyılda Fransızcada, 19. yüzyılda da İngilizcede yönetim kavramının eşiti olarak kullanılıyordu. Guy Hermet, yönetişim kavramı ile ilgili olarak beş farklı tipoloji oluşturmuştur: Kronolojik açıdan ilk olarak 1930'lı yılların sonunda kurumsal yönetişim (corporate governance) kavramı ortaya çıktı. Bunu 1950'li yıllarda kentsel yönetişim (urban governance) kavramı izledi. Üçüncü olarak yönetişim kavramı özellikle Güney Ülkeleri için kullanıldı. Bunun arkasından, küresel yönetişim (global governance) kavramı geldi. Son olarak yönetişim kavramı, Avrupa Birliği gibi ulus üstü yapıların ortaya çıkmasında kullanıld1 (Duault, 2005).

Avrupa Birliği aslında yönetişimin temel mantığına uygun bir yapı arz etmektedir. Zira Avrupa Birliği'nde karar alma süreci (Soyupek, 2012) birden fazla aktörün işin içine girdiği, çoğulcu ve şeffaf nitelik arz eden bir süreci ifade etmektedir. $\mathrm{Bu}$ yönüyle Avrupa Birliği yönetişimin adeta uygulamalı bir laboratuvarını temsil etmektedir (Chevallier, 2003). Diğer taraftan AB'nin karakterini açıklamak üzere yönetişim kavramına yeni bir açılım getirilerek çok katmanlı yönetişim (multi-level governance) kavramı ortaya atılmıştır. Çok katmanlı yönetişim kavramı, "farklı kurumsal seviyelerde hiyerarşik olmayan yatay ve dikey özel bir ilişki biçimi anlamına gelmektedir" (McCormick, 2015; Peters ve Pierre, 2004).

Yönetişim kavramı ile birlikte kullanılan bir diğer kavram da iyi yönetişimdir. İyi yönetişim de tıpkı yönetişim gibi, yeni kamu yönetimi anlayışının bazı yetersizliklerinin giderilerek gelişmekte olan ülkelere göre yeniden düzenlenmiş şekli olarak tanımlanmıştır. Kamu yönetiminin verimli işlemesi için gerekli altyapının gelişmekte olan ülkelerde bulunmaması sebebiyle bu ülkelerde piyasa ekonomisini ve demokratik yönetim anlayışını yerleştirmek için yeni kamu yönetimi anlayışına eklenen bazı ilkelerle iyi yönetişim yaklaşımının ortaya çıtığı belirtilmiştir. 1992 yılında Rio de Jeneiro'da yapılan Birleşmiş Milletler Çevre ve Kalkınma Konferansı'nın bir ürünü olarak ortaya çıkan "Gündem 21" projesi, yönetişim anlayışının yerel düzeye taşınmasında ve geliştirilmesinde önemli rol oynamıştır (Eryılmaz, 2012).

Genel ilkeleri itibarıla yönetişim ve iyi yönetişim birbirlerine benzemelerine rağmen aralarında bir takım küçük farklılıklar bulunmaktadır. Yönetişim vatandaşların yasal haklarını kullanarak çıkarlarını korumaları ve sorumluluklarının yerine getirmelerini sağlayan süreçleri ve kurumları içermektedir. İyi yönetişim; katılımcılık, şeffaflık, hesap verebilirlik ve hukukun üstünlüğü gibi ilkeler çerçevesinde siyasi, toplumsal ve ekonomik önceliklerin 
toplumda geniş uzlaşma ile belirlenmesini ve kaynakların dağıtımında tüm toplum kesimlerinin sürece dâhil edilmesini içermektedir (Aydın, 2007).

\section{B. Yönetişimin Gelişimi}

Yönetişim kavramının gelişimi, Dünya Bankası'nın yayınladığı raporlar çerçevesinde takip edilebilir. Dünya Bankası, yönetişim kavramını ilk olarak 1989 yılında yayınladığı "Sub-Saharan Africa: From Crisis to Sustainable Growth" isimli raporunda kullanmıştır. Bu raporda devlet ile toplum arasındaki ilişkilerin yeniden ele alınması gerekliliğine vurgu yapılmış ve devletin rolünün küçültülmesi gerektiği belirtilmiştir (World Bank, 1989). 1992 yılında yayınlanan raporda ise devletin yetki kullanımındaki ve kamu politikalarının oluşturulma sürecindeki rollerine dikkat çekilerek kamu yönetimi anlayışı sorgulanmış ve yeni kamu yönetimi anlayışının gerekliliği üzerinde durulmuştur (World Bank, 1992).

1994 yılındaki "Yönetişim" isimli raporunda Dünya Bankası, devletin piyasa güvencesini sağlayan ve sivil toplumun geliştirilmesi konusuna vurgu yaparak kamu hizmetini tüketenlerin de karar alma mekanizmalarına katılmaları gerektiği belirtmiş ve böylece katılımcılığ 1 yönetişimin önemli ilkelerinden biri olarak göstermiştir (World Bank, 1994). 1997 yılındaki rapor devletin küresel ekonominin gereklerine cevap verebilecek ve teknolojik değişikliklere uyum sağlayabilecek kapasite geliştirmesi gerektiğine dikkat çekmiştir. Kapasite artırımı için öncelikle yetersizlikler ortaya koyularak kapasite belirlenmeli sonra da kapasitenin artırılması gerektiği belirtilmektedir (World Bank, 1997).

Söz konusu raporlarda yönetişim üç farklı dönem geçirmiştir: İlk dönemdeki raporlara minimal devlet anlayışı hâkim iken 1994 yılında yayınlanan ve ikinci dönemi oluşturan raporda sivil toplum örgütlerinin yönetişimdeki önemine vurgu yapılmıştır. 1997 yılında yayınlanan ve üçüncü dönem olarak nitelendirilebilecek dönemdeki raporlarda ise yönetişimde devletin rolüne dikkat çekilerek devletin güçlendirilmesi gerektiği belirtilmiştir (Bayramoğlu, 2002). Dünya Bankası'nın yönetişim kavramı dolayısıyla devletin rolünde yaptığ değişikliğin temel sebebi, gelişmekte olan ülkelerdeki altyapı eksikliğinin ancak etkin bir devlet vasıtasıyla giderilebileceği gerçeğidir. Etkin bir piyasa mekanizması ancak altyap1 eksikliklerini gidermiş bir devlette gerçekleşebileceğinden devletin küçültülmesinden ziyade etkin olması gerektiği vurgulanmaya başlanmıştır (Bayramoğlu, 2002).

Dünya Bankası'nın yönetişim stratejisi iki temel bileşenden oluşmaktadır. Birincisi hukuki ve siyasi reformlar çerçevesinde gelişirken ikinci strateji devlet dışı aktörlerin karar alma ve uygulama sürecine dâhil edilmesi şeklinde olmuştur. Hukuki ve siyasi reformların amacının küreselleşme yolunda ilerleyen dünya ekonomik sistemine dâhil olmayan ülkeleri, özellikle Sovyetler Birliği’nin dağılmasından sonra ortaya çıkan Orta ve Doğu Avrupa ülkelerini küresel pazarla bütünleştirebilmek için ortaya atılmış bir yöntem olduğu şeklinde görüşler de bulunmaktadır (Zabc1, 2002).

Bütün bu raporlar ve 1970'li yıllarda başlayan krizler ve gelişmeler (küreselleşme, ulus devletin zayıflaması, yönetim krizi, kamu kesiminin 
yetersizliği, geri kalması, sorun çözmekten uzak yap1s1) yönetişimin ortaya çıkmasındaki genel yapıyı göstermesi bakımından ilginçtir.

\section{Yönetişim, Yönetim Ve Yeni Kamu Yönetimi İliş̧kisi}

1970'li yıllardan itibaren geleneksel kamu yönetimine ciddi eleştiriler getirilmeye başlandı. Söz konusu eleştirilerin başında ulusal hükümetlerin kamu politikalarının belirlenmesinde temel aktör olması, bu politikaların belirlenmesi ve uygulanmasında başka aktörlere yer vermemesi, ulusal hükümetlerin faaliyetleriyle toplumu ve ekonomiyi etkiledikleri eleştirileri gelmektedir. Ulusal hükümetlerin kamu politikalarının belirlenmesi ve uygulanmasındaki bu baskın durumlarına yönelik hem uluslararası piyasalardan ve hem de Avrupa Birliği gibi uluslar üstü örgütlerden gelen baskılar söz konusu hükümetleri ciddi küresel bask1 altına almıştır (Peters ve Pierre, 1998).

Weber'in bürokrasi yaklaşımına dayanan yönetim anlayışının ciddi krizlerle karşı karşıya kalması yeni yönetim anlayışlarının ortaya çıkmasında önemli rol oynamıştır. Kamu yönetimine yöneltilen eleştiriler, iletişim ve teknoloji alanındaki gelişmeler, özel sektördeki dinamik yapı ve buna bağlı olarak elde edilen başarı kamu yönetimi anlayışında da değişmelerin olması gerektiği yönünde düşüncelere sebep olmuştur (Bilgiç ve Göksu, 2004).

Yönetim anlayışındaki bu değişim; yönetimin kamusal yönünden ziyade özel yönünün ön plana çıkması, doğrudan hizmet sunma yerine "imkân sağlama" ve "düzenleme" (hükümetin rolünün yeniden tanımlanması), hizmet sunumunda kamunun yanı sıra özel sektör ve sivil toplum kuruluşlarının da yer almaya başlaması, özel sektör yönetim tekniklerinin kamuda da kullanılmaya başlaması (hiyerarşik sistemden ağ sistemine geçilmesi) gibi yeni yönetim teknik ve yöntemlerinin kullanılması gerektiği düşüncesini doğurmuştur (Heywood, 2014).

Anglo-Amerikan kullanımda yönetim (government) kelimesi, devletin formal kurumlarına ve onların iktidarı kullanımındaki tekelliğine işaret etmektedir. Yönetim, karar alma ve uygulama kapasitesi ile karakterize edilmektedir. Yönetişim kavramının geleneksel kullanımı, yönetim kavramı ile eşanlamlıdır (Stoker, 1998). Fakat yönetişim yönetim anlamında kullanılmamaktadır. Zira yönetişim yönetimden daha kapsamlı olup devlet dışı aktörleri de kapsayan bir süreci ifade etmektedir (Rhodes, 1996). Yönetişim aslında yönetimden kaynaklanan problemlerden ortaya çıkmıştır. Yönetişim hükümetin ve diğer sosyal aktörlerin nasıl etkileşim içinde olduklarını, vatandaşlarla nasıl ilişki içinde olduklarını ve bu kompleks yapı içinde nasıl karar alındığı açıklamaktadır (Graham ve ark., 2003).

Kamu yönetimi alanındaki bu krizlerin yanında özellikle 1970'li ve 1980'li yıllarda sosyal bilimlerde yaşanan paradigmatik krizler de yeni yaklaşımların ortaya çıkmasında önemli rol oynamıştır. Sosyal bilimler bu dönemde; ekonomide piyasa ile hiyerarşi, siyasada (policy) piyasa ile planlama, politikada özel ile kamu, uluslararası ilişkilerde bağımsızlık ile anarşi arasındaki dikotomiye tatmin edici bir açıklama getirememiştir (Jessop, 1998). Bu gelişmelere paralel olarak kamu yönetiminde de bir paradigma değişimi süreci yaşanmış ve yönetişim kavramı 
aslında bu paradigma değişiminde duraklardan birisi olmuştur. 1980'li yıllara kadar kamu yönetimi (public administration) olarak gelen paradigma, önce kamu işletmeciliği (public management), ardından yeni kamu yönetimi (new public management), 1990'lı yılarda da yönetişim (governance) olarak değişiklik yaşamıştır (Güler, 2003). Yönetişim ile söz konusu süreçte kullanıma giren yaklaşımlar arasında benzerliklerin yanında bir takım farklılıklar da bulunmaktadır.

Bazı yazarlar yönetişim tartışmalarının yeni kamu yönetimi uzmanları tarafından yönetim felsefesi tartışmaları tarafindan tetiklendiğini ileri sürmektedirler (Peters ve Pierre, 1998). Yönetişim ile yeni kamu yönetimi anlayış1 birbirine yakın olsa da aralarında önemli farklılıklar vardır. Kamu yönetiminin yönetim metodu hiyerarşik ilişki üzerine kuruluyken, yeni kamu yönetiminde piyasa ilkelerine ve eşitliğe dayalı yönetim anlayışı söz konusudur. Yönetişimde ise aktörlerin karşılıklı bağlılık anlayışı hâkimdir. Kamu yönetiminde idare hukuku esas ve ilkeleri, yeni kamu yönetiminde daha çok sözleşmeler, yönetişimde ise anlaşmalar esastır. Kamu yönetimi bürokratik yönetim usulüne dayanırken, yeni kamu yönetimi anlayışı işletmeci esaslara, yönetişim ise ortaklık ve danışma esasına dayanır. Kamu yönetiminde devletin vatandaşları üzerinde üstünlüğü ve hâkimiyeti söz konusu iken yeni kamu yönetiminde rekabet ve işbirliği iç içedir. Yönetişimde ise aktörler arasında eşitlik ve karşılıklı bağımlılık söz konusudur. Kamu yönetiminde faaliyetlerin amacı düzenin güçlendirilmesi, yeni kamu yönetiminde değişimi teşvik etme, yönetişimde ise sosyal güveni kurmadır. Kamu yönetiminde faaliyetler dayanağını prosedürlerden alırken yeni kamu yönetiminde sonuçlara odaklanılmıştır. Yönetişimde ise ihtiyaçlara odaklanma söz konusudur. Kamu yönetimi devletin üniter yapıda olması gerektiğine işaret ederken yeni kamu yönetimi özerk yapılara yer vermekte, yönetişim ise sivil toplum kuruluşlarını öne çıkarmaktadır (Czaputowicz, 2010).

Hem yönetişimde hem de yeni kamu yönetiminde hesap verebilirlik konusu çözümlenmemiş olarak durmaktadır. Yönetişim teorisyenleri geleneksel hesap verebilirliğin yerine "paydaşçıllk" (stakeholderism) gibi farklı kontrol süreçlerinin koyulabileceğini ileri sürmektedirler. Buradan anlaş1lıyor ki, hesap verebilirlik, yönetişim literatüründe biraz daha zayıf kalmaktadır. Her iki teoride de temel sorun, kontrol ve hesap verebilirlik arasında bağlantının karışmış olmasıdır (Peters ve Pierre, 1998).

Bu farklılıkların yanında her iki yaklaşımda da ortak yönler bulunmaktadır. Her iki yaklaşımda da, kamu yönetiminin toplumun geri kalanından izole edildiği fikri ağır basmaktadır. Tüzel aktörler piyasa rekabetinin altında sofistike yönetim ve kaynakların dağıtımı modeli geliştirirken, kamu bürokrasisi ekonomik baskılardan izole edilmiş kalmaktadır. Sonuçta; kurumsal gevşeklik, yaygın etkisizlik, ekonomik rehavet, süreçlere takıntı, müşteri ihtiyaçlarında tatminsizlik gibi durumlar ortaya çıkmaktadır (Peters ve Pierre, 1998).

\section{Yönetişimin Teorik Ve Düşünsel Temelleri}

Yönetişimin teorik temellerine ilişkin tartışmalar, devletin fonksiyonlarına yönelik tartışmalarla birlikte başlamıştır. Devletin yapısına ve işleyişine getirilen 
eleştiriler yeni arayışlarla birlikte yeni yaklaşımların ortaya çıkmasına sebep olmuştur. Özellikle ekonomik kriz ile başlayan ve siyasi krizlerle devam eden ve nihayetinde Sovyetler Birliği’nin dağılmasıyla sonuçlanan krizler döneminde tartışmalar, devletin “yönetebilirlik krizi” çerçevesinde gelişmiştir. Yönetebilirlik krizi, devletin hem ulusal hem de uluslararası çapta bir yönetim krizi içinde bulunduğunu ileri sürmektedir. Ulus devlet formu küreselleşme karşısında zayıflarken yönetim krizi içine girmiş ve bu krizden çıkamamıştır. Yönetişimin ortaya çıkmasındaki temel etken yöneten-yönetilen ilişkisinin ne şekilde olması gerektiği şeklindedir (Bayramoğlu, 2002).

1970'li y1llarda ekonominin yeniden krize girmesiyle birlikte gözler devlet yaklaşımına çevrilmiştir. Durgunlukla birlikte enflasyon, işsizlik ve bütçe açıklarının artması, küresel rekabetin gittikçe daha acımasız hale gelmesinin ardından Keznesyen politikalar ve refah devleti anlayışı sorgulanır hale gelmiştir. Özel sektördeki dinamik yapının kamu sektöründe de olması gerektiğini ileri süren liberal yaklaşım yönetişim kavramına sık sık vurgu yapmaya başlamıştır. Bu yeni anlayış içerisinde; katılım, ekip çalışması, bireysel inisiyatif, sürekli gelişim, rakiplere karşı yeni strateji geliştirme gibi yeni yönetim anlayışına uygun unsurlar ön plana çıkmaya başlamıştır. Bütün bunların karşısında kamu yönetiminin kendisinden beklenilen hizmetleri sunmada yetersiz kalması, sivil toplum örgütlerinin kamunun yetersiz kaldığı bu alanlarda aktif bir şekilde ortaya çıkmasına sebep olmuştur. Bireylerin ve toplumun kamu hizmetleri konusunda günden güne artan istek ve talepleri de yönetişim kavramını savunanların tezlerini güçlendirmiştir (Dinçer ve Yılmaz, 2003).

Yüzyılın başında kalkınmanın ana faktörü, itici gücü ve krizlerden çıkış yolu olarak başvurulan devlet 20. yüzyılın sonuna doğru ekonomik krizlerin ve yönetim krizlerinin müsebbibi olarak görülmüştür. Krizden çıkış yöntemi olarak yeniden yapılanma çalışmalarına ihtiyaç olduğu öne sürülmüştür. İç ve dış etkenlerin zorlamasıyla yönetim anlayışının nasıl olması gerektiğine yönelik tartışmalar kamu yönetiminde yeni yaklaşımların yönünü tayin etmiştir. Devletin yap1 ve işlevine getirilen eleştiriler, yöneten-yönetilen ilişkisinin yeniden tanımlanma ihtiyacı kamu yönetiminde yeni yaklaşım ve uygulamaların ortaya çıkmasına ve gelişmesine yol açmıştır.

$\mathrm{Bu}$ dönemde kamu yönetiminde değişimin yönü, devletin kamu hizmetlerinin yürütülmesine doğrudan katılımı yerine denetim ve gözetimine doğru olmuştur. Dolayısıyla devlet artık hizmeti yerine getirmekten ziyade yetki veren, bürokratik süreçler yerine piyasa süreçlerine öncelik veren, halkını yönetilen olarak değil de müşteri olarak gören ve bürokrasi yerine halkın ihtiyaçlarını önceleyen, harcama yerine kazanmayı amaçlayan, iyileştirme yerine korumayı önceleyen ve hiyerarşiden ziyade katılım ve takım çalışmasına değer veren bir kurum olarak ele alınmaktadır (Frederickson, 1996). Tüm bu değişikliklerden sonra devlet, nicel anlamda küçülerek nitel anlamda etkin ve verimli kılınmaya çalışılmış ve vatandaşın da yönetime katılarak devletin esas işlerine dönmesi arzulanmıştır (Bilgiç, 2011). 
Yönetişim kavramı aslında uzun süredir kullanılan bir paradigmanın, devletin toplumu tek başına yöneten aktör olduğu paradigmasının değişimine işaret etmektedir. Zira yönetişim anlayışının ortaya çıkıp geliştirilmesiyle birlikte artık, devlet toplumu tek başına yöneten bir aygıt olmaktan çıkmış, iktidarını ve yönetme gücünü başka aktörlerle paylaşan hatta bu gücünün büyük bir kısmını onlara devreden ve kendisi onlara denetmenlik ve gözetmenlik yapan bir hakem olarak görülmeye başlandı. Bu durum "kamu kudretinin doğrudan sermayeye teslim edilmesi" (Güler, 2003) şeklindeki eleştirileri de beraberinde getirmiştir.

Güler, yönetişim yaklaşımının; ekonomi alanında kurumcu iktisat yaklaşımından, kamu yönetimi alanında yeni kamu işletmeciliği yaklaşımından, yönetim ve organizasyon alanında yatay, esnek ve ağ tipi örgüt kuramlarından ve son olarak uluslararası ilişkiler alanında küreselleşme yaklaşımından destek aldığını ileri sürmektedir (Güler, 2003).

Yönetişime getirilen eleştiriler, yönetişimin yönetimin temel değerlerini dışladığı, yönetimin etik değerlerinin yerini liberalleştirme, özelleştirme ve deregülasyon gibi bir takım yeni değerlerin aldığı şeklindedir. Ayrıca yönetişim işin özünden ziyade biçimle ilgilenmekte ve "yönetişim" kavramının hiçbir çağrışım yapmadığı belirtilmektedir. Yönetişim kavramının genel olarak postmodernizm ve özel olarak postmodern yönetim tartışmasından etkilendiği kabul edilmektedir (Aydın, 2007).

\section{METODOLOJI}

Çalışma kapsamında Legatum Prosperity Index tarafindan hazırlanan veriler kullanılarak ikincil veri analizi yapılmıştır. Söz konusu indeks kapsamında 142 ülke yer almakta olup, indeks, ülkelerin iyi yönetişim sıralamasını; yönetimde istikrar, yönetimde etkililik, hukukun üstünlüğ̈̈, kuvvetler ayrılığı, siyasi haklar, yarg1 sistemine, orduya ve seçimlerin dürüstlüğüne güven gibi kriterlere göre yapmaktadır (The Legatum Prosperity Index, 2015).

Eğitim, sağl1k, ekonomi ve bireysel özgürlüklerin yönetişim üzerindeki etkisini ölçmek için bazı analizler yapılmıştır. Analizlerde bağımlı değişken olarak yönetişim, bağımsız değişkenler olarak ise eğitim, sağlık, ekonomi ve bireysel özgürlükler alınmıştır. Değişkenler arasındaki ilişkiyi ölçmek için korelasyon analizi, gruplar arasında anlamlı bir farkın olup olmadığını belirleyebilmek için Tek Yön ANOVA analizi ve aralarındaki ilişkinin nedenini açıklayabilmek için regresyon analizleri yapılmıştır.

\section{III.ANALIZ VE BULGULAR}

Veri setindeki 142 ülkenin bölgelere göre dağılımı tablodaki gibidir. Ülkeler bulundukları coğrafi bölgelere göre gruplara ayrılmıştır. İndekste Sahra altı Afrika bölgesinden 34 ülke yer almakta olup bu sayı toplam ülkelerin \% 23,9'unu oluşturmaktadır. Asya-Pasifik bölgesinden 26 ülke bulunmakta ve bu sayı toplam sayının \% 18,3'üne karşılık gelmektedir. İndekste en fazla veriler Avrupa bölgesindeki ülkelerden bulunmaktadır. Toplam 43 ülkenin yer aldığı bu bölgenin oranı toplam sayı içerisinde \% 30,3'tür. En az ülke ise Orta Doğu bölgesinden bulunmaktadır. 15 ülke toplam sayı içerisinde \% 10,6'lık bir oranı oluşturmaktadır. 
Amerika bölgesinden ise 24 ülke yer almakta olup bu sayı toplam sayının \% 16,9'unu oluşturmaktadır.

Tablo 1. Veri Setindeki Ülkelerin Bölgelere Göre Sayısı ve Oranı

\begin{tabular}{|l|r|r|r|r|}
\hline \multicolumn{5}{|c|}{ PI-Region } \\
\hline & Frequency & Percent & Valid Percent & Cumulative Percent \\
\hline Sahra altı Afrika & 34 & 23,9 & 23,9 & 23,9 \\
Asya-Pasifik & 26 & 18,3 & 18,3 & 42,3 \\
Avrupa & 43 & 30,3 & 30,3 & 72,5 \\
Orta Doğu & 15 & 10,6 & 10,6 & 83,1 \\
Amerika & 24 & 16,9 & 16,9 & 100,0 \\
Toplam & 142 & 100,0 & 100,0 & \\
\hline
\end{tabular}

Ülkelerin yönetişim, eğitim, sağlık, ekonomi ve bireysel özgürlük sıralamaları aldıkları puana göre hesaplanmıştır. Bu sıralama ülkelerin yer aldıkları bölgelere göre değişiklik göstermekte midir?

Tablo 2. Bölgelerin Yönetişim, Eğitim, Sağlık, Ekonomi ve Bireysel Özgürlük Ortalamaları

\begin{tabular}{|l|c|c|c|c|c|}
\hline Bölgeler & Yönetişim & Eğitim & Sağlık & Ekonomi & $\begin{array}{c}\text { Bireysel } \\
\text { Özgürlük }\end{array}$ \\
\hline $\begin{array}{l}\text { Sahra altı } \\
\text { Afrika }\end{array}$ & 102,28 & 121,85 & 122,61 & 109,88 & 85,52 \\
\hline Asya-Pasifik & 67,07 & 62,88 & 68,65 & 54,61 & 74,19 \\
\hline Avrupa & 44,81 & 34,32 & 35,20 & 55,30 & 53,34 \\
\hline Orta Doğu & 84,13 & 74 & 67,46 & 71,33 & 116,6 \\
\hline Amerika & 72,45 & 74,54 & 69,70 & 64,54 & 53,04 \\
\hline
\end{tabular}

Yönetişim sıralamasına bakıldığında Avrupa ülkelerinin sıralamasının diğer ülkelere göre daha ön siralarda oldukları görülmektedir $(M=44,81)$. Avrupa ülkelerini Asya- Pasifik ülkeleri $(M=67,07)$, Amerika ülkeleri $(M=72,45)$ ve Orta Doğu ülkeleri $(\mathrm{M}=84,13)$ takip etmektedir. Bu siralamada Sahra altı Afrika ülkeleri ise 102,38 ortalamayla en arka siralarda yerlerini almaktadır.

Eğitim sıralamasına bakıldığında yine Avrupa ülkelerinin en ön sıralarda bulunduğu görülmektedir $(\mathrm{M}=34,32)$. Avrupa ülkelerini Asya-Pasifik ülkeleri $(M=62,88)$ ve birbirlerine yakın ortalamayla sirasıyla Orta Doğu $(M=74)$ ve Amerika $(M=74,54)$ takip etmektedir. Eğitim siralamasında Sahra altı Afrika ülkeleri 121,85 ortalamayla en arka siralarda yer almaktadırlar.

Sağlık siralamasında da ön siralar yine Avrupa ülkeleri tarafindan doldurulmaktadır $(M=35,20)$. Daha sonra birbirine yakın ortalamayla sirası ile Orta 
Doğu ülkeleri $(M=67,46)$, Asya-Pasifik ülkeleri $(M=68,65)$ ve Amerika ülkeleri $(\mathrm{M}=69,70)$ izlemektedir. Bu siralamada son siraları Sahra altı Afrika ülkeleri almaktadır $(\mathrm{M}=122,61)$.

Ekonomi siralamasinda ön siralarda bu kes Asya-Pasifik ülkeleri yer almakta $(M=54,61)$, Avrupa ülkeleri hemen arkasindan gelmektedir ( $M=55,30)$. Amerika ülkeleri 64,54 ortalama, Orta Doğu ülkeleri ise 71,33 ortalama ile onlar1 takip etmektedirler. Son siralarda Sahra altı Afrika ülkeleri bulunmaktadır $(\mathrm{M}=109,88)$.

Bireysel özgürlük sıralamasında ise en ön sıralarda birbirine çok yakın ortalamalarla Amerika ülkeleri $(\mathrm{M}=53,04)$ ve Avrupa ülkeleri $(53,35)$ yer alırken, bunlar1 Asya-Pasifik ülkeleri $(M=74,19)$ Sahra altı ülkeleri $(M=85,52)$ takip etmektedir. Bu alanda en arka sıraları ise Orta Doğu ülkeleri doldurmaktadır $(\mathrm{M}=116,6)$.

Tablo 3. Tek Yön Anova Analizi

\begin{tabular}{|c|c|c|c|c|c|c|}
\hline \multicolumn{7}{|c|}{ ANOVA } \\
\hline & & $\begin{array}{l}\text { Sum of } \\
\text { Squares }\end{array}$ & $\mathrm{df}$ & Mean Square & $\mathrm{F}$ & Sig. \\
\hline \multirow{3}{*}{ Yönetişim Sıra } & Between Groups & 65973,421 & 4 & 16493,355 & 13,090 & 000 \\
\hline & Within Groups & 172622,079 & 137 & 1260,015 & & \\
\hline & Total & 238595,500 & 141 & & & \\
\hline \multirow{3}{*}{ Ekonomi Sıra } & Between Groups & 69945,455 & 4 & 17486,364 & 14,205 &, 000 \\
\hline & Within Groups & 168650,045 & 137 & 1231,022 & & \\
\hline & Total & 238595,500 & 141 & & & \\
\hline \multirow{3}{*}{ Eğitim Sıra } & Between Groups & 147873,181 & 4 & 36968,295 & 55,826 & 000 \\
\hline & Within Groups & 90722,319 & 137 & 662,207 & & \\
\hline & Total & 238595,500 & 141 & & & \\
\hline \multirow{3}{*}{ Sağlık Sıra } & Between Groups & 146005,778 & 4 & 36501,445 & 54,009 &, 000 \\
\hline & Within Groups & 92589,722 & 137 & 675,837 & & \\
\hline & Total & 238595,500 & 141 & & & \\
\hline \multirow{3}{*}{$\begin{array}{l}\text { Bireysel Özgürlük } \\
\text { Sıra }\end{array}$} & Between Groups & 59734,665 & 4 & 14933,666 & 11,439 & ,000 \\
\hline & Within Groups & 178860,835 & 137 & 1305,554 & & \\
\hline & Total & 238595,500 & 141 & & & \\
\hline
\end{tabular}


ANOVA sonuçları yukarıdaki tabloda verilmiştir. Buna göre yönetişimi değişkeni ile ekonomi, eğitim, sağlık ve bireysel özgürlük değişkenleri arasında istatistiksel olarak anlamlı bir farklılık gözükmektedir.

\section{KORELASYON ANALIZİ}

Tablo 4. Korelasyon Analizi

\begin{tabular}{|c|c|c|c|c|c|c|c|}
\hline & \multicolumn{7}{|c|}{ Korelasyon Matriks } \\
\hline & & & 1 & 2 & 3 & 4 & 5 \\
\hline 1 & Yönetişim Skoru & $\mathrm{r}$ & 1 & & & & \\
\hline & Ekonomi Skoru & $\mathrm{r}$ &, $759^{* *}$ & 1 & & & \\
\hline & Eğitim Skoru & $\mathrm{r}$ &, $707^{* *}$ &, $710^{* *}$ & 1 & & \\
\hline 4 & Sağlık Skoru & $\mathrm{r}$ &, $769^{* *}$ &, $763^{* *}$ &, $909^{* *}$ & 1 & \\
\hline 5 & Bireysel Özgürlük Skoru & $\mathrm{r}$ &, $776^{* *}$ &, $597^{* *}$ &, $516^{* *}$ &, $559^{* *}$ & 1 \\
\hline
\end{tabular}

Değişkenlerin birbirleriyle birebir olan ilişkilerini gösteren korelasyon matriksi tablosuna göre tüm değişkenler birbirleriyle istatistiksel olarak anlamlı bir ilişkiye sahiptirler. İlişkilerin yönü pozitif ve hepsi kuvvetli ilişki göstermektedir. Ayrıca çoklu regresyon analizinde dikkat edilmesi gereken bir uyarı da bu korelasyon matriks tablosunda ortaya çıkmaktadır. Bu da eğitim skoru değişkeni ile sağlik skoru değişkeni arasındaki çok yüksek korelasyondur $(0,909)$. Bu kadar yüksek bir korelasyon bu iki değişken arasında Multicollinearity sorununa işaret edebilir. Bu nedenle çoklu değişken analizinde bu iki değişkenin multicollinearity analizine dikkat etmek gerekmektedir. Multicollinearity kabaca iki farklı değişkenini aynı şeyi ölçmesi durumu olarak adlandırılabilir.

\section{ÇOKLU DEĞISSKKEN ANALIZí}

Çoklu değişken analizinden önce gerekli varsayım testleri yapılmış ve veri seti çoklu değişken analizine hazır hale getirilmiştir. Korelasyon analizinde de uyarı veren multicollinearity sorunu, çoklu analizde test edilmiş, fakat VIF skorlarından hiçbirisi eşik değer olan 10'un üzerinde olmadığından değişkenler oldukları haliyle çoklu analize sokulmuşlardır.

Tablo 5. Çoklu Değişken Analizi

Model Summary ${ }^{b}$

\begin{tabular}{|l|r|r|r|r|}
\hline Model & $\mathrm{R}$ & R Square & $\begin{array}{c}\text { Adjusted R } \\
\text { Square }\end{array}$ & Std. Error of the Estimate \\
\hline 1 &, $886^{\mathrm{a}}$ &, 785 &, 778 &, 921 \\
\hline
\end{tabular}


a. Predictors: (Constant), Bireysel Özgürlük Skoru, Eğitim Skoru, Ekonomi Skoru, Sağllk Skoru

b. Dependent Variable: Yönetişim Skoru

Çoklu değişken analizinde, teste tabi tutulan bağımsız değişkenlerin, bağımlı değişken olan yönetişim skordaki varyansın \%78,5'unu açıklayabildikleri görülmektedir $\left(\mathrm{R}^{2}=0,785\right)$.

Tablo 6. ANOVA

ANOVA ${ }^{a}$

\begin{tabular}{|rl|r|r|r|r|r|}
\hline \multicolumn{1}{|c|}{ Model } & & \multicolumn{1}{c|}{ Sum of Squares } & df & Mean Square & \multicolumn{1}{c|}{ F } & \multicolumn{1}{c|}{ Sig. } \\
\hline \multirow{2}{*}{1} & Regression & 419,949 & 4 & 104,987 & 123,791 &, $000^{\mathrm{b}}$ \\
& Residual & 115,342 & 136 &, 848 & & \\
& Total & 535,291 & 140 & & & \\
\hline
\end{tabular}

a. Dependent Variable: Yönetişim

b. Predictors: (Constant), Bireysel Özgürlük, Eğitim, Ekonomi, Sağlik

Çoklu değişken analizinin ANOVA testinin anlamlı olması da modeldeki değişkenlerden en az bir tanesinin bağımlı değişkenler ile anlamlı bir ilişkisi olduğunu göstermektedir.

Tablo 7. Coefficients

Coefficients $^{\mathrm{a}}$

\begin{tabular}{|c|c|c|c|c|c|c|c|c|}
\hline \multirow{2}{*}{\multicolumn{2}{|c|}{ Model }} & \multicolumn{2}{|c|}{$\begin{array}{c}\text { Unstandardized } \\
\text { Coefficients }\end{array}$} & \multirow{2}{*}{$\begin{array}{c}\begin{array}{c}\text { Standardize } \\
\mathrm{d}\end{array} \\
\text { Coefficients } \\
\text { Beta }\end{array}$} & \multirow[t]{2}{*}{$\mathrm{t}$} & \multirow[t]{2}{*}{ Sig. } & \multicolumn{2}{|c|}{$\begin{array}{c}\text { Collinearity } \\
\text { Statistics }\end{array}$} \\
\hline & & $\mathrm{B}$ & Std. Error & & & & Tolerance & VIF \\
\hline \multirow{5}{*}{1} & (Constant) &,- 533 & ,097 & & $\begin{array}{r}- \\
5,506\end{array}$ & , 000 & & \\
\hline & Ekonomi & ,296 & ,083 &, 231 & 3,553 & ,001 & ,375 & 2,670 \\
\hline & Eğitim &, 011 & ,092 &, 011 & , 119 & ,905 & ,173 & 5,769 \\
\hline & Sağlık &, 319 &, 101 &, 331 & 3,154 & ,002 &, 144 & 6,963 \\
\hline & $\begin{array}{l}\text { Bireysel } \\
\text { Özgürlük }\end{array}$ & ,447 &, 051 & ,446 & 8,794 & ,000 & ,616 & 1,625 \\
\hline
\end{tabular}

a. Dependent Variable: Yönetişim 
OLS regresyon analizi sonuçları yukarıdaki tabloda verilmiştir. Bu sonuçlara göre eğitim değişkeni ile bağımlı değişken arasında istatistiksel olarak anlamlı bir ilişki yoktur. Diğer değişkenler olan ekonomi, sağlık ve bireysel özgürlük değişkenlerinin istatistiksel olarak anlamlı ve pozitif yönlü olarak bağımlı değişken ile ilişkileri vardır.

Ekonomi değişkeni bir standart birim artarken, bağımlı değişken olan yönetişim değişkeni 0,231 standart birim artmaktadır $(\beta=0,231 ; p<0,01)$. Diğer bir ifade ile ülkelerin ekonomileri iyileştikçe, yönetişimi de iyileşmektedir.

Sağlık değişkeni bir standart birim artarken, yönetişim değişkeni 0,331 birim artmaktadır $(\beta=, 331 ; \mathrm{p}<0,001)$. Aynı şekilde sağlık sistemi daha iyi olan ülkenin yönetişimi de daha iyi olmaktadır.

Bireysel özgürlük değişkeni bir standart birim artarken yönetişim değişkeni 0,446 birim artmaktadır $(\beta=, 446 ; \mathrm{p}<0,001)$. Başka bir ifade ile bireysel özgürlüklerin gelişmiş olduğu ülkelerde yönetişimin de gelişmiş olduğu söylenebilir.

\section{TARTIŞMA VE SONUÇ}

İlk kez Dünya Bankası'nın 1989 yılında Sahra altı Afrika ülkeleri için hazırladığı raporda yer verilen yönetişim, bu ülkelerin içinde bulundukları yönetim krizinden çıkmalarının ve sürdürülebilir kalkınmayı sağlamalarının temel yolu olarak gösterilmişti. Sahra altı Afrika ülkelerinin yönetişim sıralamasında diğer ülkelerden bir hayli geride kalması kısa sürede aşılması zor olan sorunların hâlâ yerinde durduğunu göstermektedir. 1997 yılında yayınlanan raporda da belirtildiği gibi, gelişmekte olan ülkelerdeki altyap1 eksikliğinin ancak etkin bir devlet vasıtasıyla giderilebilmesi, devletin yönetişim kalitesinin yükseltilmesi için ekonomi, sağlık ve bireysel özgürlükler kategorilerine ayrı bir önem vermesi gerekmektedir.

Çalışmada eğitim, sağlık, ekonomi ve bireysel özgürlüklerin yönetişim ile ilişkisi araştırılmıştır. Çalışmanın sonucunda eğitimin yönetişim ile ilişkisi bulunmazken, sağlık, ekonomi ve bireysel özgürlüklerin yönetişim ile pozitif yönde bir ilişkisi tespit edilmiştir. Bir ülkenin sağlık, ekonomi ve bireysel özgürlük puanları arttığında yönetişim puanın da artması, yönetişim kalitesinin sağlık, ekonomi ve bireysel özgürlük gibi değişkenlere bağlı olduğunu ortaya koymaktadır. 142 ülke içerisinde ekonomi, sağlık ve bireysel özgürlük puanları yüksek olan ülkelerin yönetişim puanının da yüksek olması yönetişim kalitesini artırmanın yolunun söz konusu alanlarda kalitenin yükseltilmesi gerektiğini ortaya koymaktadir.

Bireysel özgürlük ile yönetişim arasındaki pozitif yönlü ilişki diğer değişkenlerden daha farklı bir düzeyde seyretmektedir. Bireysel özgürlük ile yönetişim arasında kuvvetli bir pozitif ilişki bulunmaktadır. Bireysel özgürlük ne kadar artarsa yönetişim skorunun da o derece artacağı ortaya çıkmıştır. Yönetişimin en önemli ilkelerinden birisi ve onu diğer yönetim anlayışlarından ayıran farklardan en önemlisi yönetişimde katılımcılığın ön plana çıkmasıdır. Katılımcılık ancak bireysel özgürlüklerin tanındığı bir toplumda gerçekleşebilecektir. Bu durum da 
aslında yönetişim ile bireysel özgürlük arasındaki pozitif yönlü ilişkinin sebebini ortaya koymaktadir.

Yönetişim kalitesini artırmanın ve yönetişim anlayışını hâkim kılmanın yolu; ülkelerin sağlık, ekonomi ve özellikle bireysel özgürlük seviyelerini artırmaktan geçmektedir. Çalışma alanda daha önce yapılmayan bir analizi ortaya koymakta ve yapılacak diğer analizler için bir başlangıç olabilme beklentisini taşımaktadır. Çalışmada yer verilen değişkenlerin dışında yönetişimi etkileyen veya yönetişim ile ilişkisi bulunan diğer değişkenlerin incelenmesi de diğer çalışmaların konusunu oluşturabilecektir.

\section{KAYNAKÇA}

Aydın, A. H. (2007). Yönetim Bilimi. Ankara: Seçkin.

Bayramoğlu, S. (2002). Küreselleşmenin Yeni Siyasal İktidar Modeli: Yönetişim. Praksis, 7, 85-116. Bilgiç, V. K. \& Göksu, T. (2004). Yeni Gelişmeler Işığında Türkiye'de Kamu Yönetimi ve Yerelleşme Eğilimleri. 2004 Türkiye İktisat Kongresi, 5-9 Mayıs 2004, İzmir, 2004, Kamuda İyi Yönetişim Tebliğ Metinleri, Cilt 10, (s.35-63). Ankara: DPT.

Bilgiç, V. K. (2011). Küreselleşme Sürecinde Kamu Yönetiminde Dönüşüm, Bekir Parlak (Ed.), Kamu Yönetiminde Yeni Vizyonlar (s. 93-118). Bursa: Alfa Aktüel.

Chevallier, J. (2003). La gouvernance, un nouveau paradigme étatique?, Revue française d'administration publique, $\mathrm{n}^{\circ}$ 105-106.

Czaputowicz, J. (2010). Training and Capacity Building for Good Governance, http://sna.gov.it/www.sspa.it/wp-content/uploads/2010/04/Jacek_Czaputowicz_NationalSchool-of-Administration-_KSA.pdf, 02.01.2016.

Çukurçayır, M. A, Eroğlu, H. T. \& Uğuz, H. E. (2010). Yönetişim Kuram, Boyutlar ve Uygulama. Ankara: Çizgi Kitabevi.

Dinçer, Ö. \& Yılmaz, C. (2003). Kamu Yönetiminde Yeniden Yapılanma: I Değişimin Yönetimi İçin Yönetimde Değişim, Ankara: Başbakanlık.

Duault, L. A. (2005). Les ONG à l'heure de la Bonne Governance. Autrepart, n.35.

Ergen, Z. (2012). Yönetimden Yönetişime: Katılımcı Bütçeleme Modeli. Maliye Dergisi, 163, 316334.

Eryılmaz, B. (2012). Kamu Yönetimi, Genişletilmiş 5. Baskı, Kocaeli: Umuttepe.

Frederickson, H. G. (1996). Comparing the Reinventing Government Movement with the New Public Administration. Public Administration Review, 56 (3), 262-271.

Gaudin, J.P. (1998). Modern Governance, yesterday and today some clarification to be gained from French government policies. International Social Science Journal. 50 (155), 47-56.

Government Governance: Corporate governance in the public sector, why and how? Çeviri: Özeren, B. \& Temizel, Ö. (2004). Kamusal Yönetişim: Kamu Sektöründe Kurumsal Yönetişim, Niçin ve Nasıl. Sayıştay Yayınları.

Graham, J., Amos B. \& Plumptre, T. (2003). Principles for Good Governance in the $21^{\text {st }}$ Century. Ontario: Institute on Governance.

Güler, B. A. (2003). Yönetişim: Tüm İktidar Sermayeye. Praksis, 9, 93-116.

Gültekin, S. (2011). New Public Management: Is it really new? International Journal of Human Sciences. 8 (2), 343-358.

Heywood, A. (2014). Küresel Siyaset. Nasuh Uslu ve Haluk Özdemir (Çev.). Ankara: Adres.

Hughes, O. E. (2012). Public Management and Administration An Introduction. Fourth Edition, Palgrave Macmillan.

Jessop, B. (1998). The rise of governance and the risks of failure: The case of economic development. International Social Science Journal, 50 (155), 29-45.

Kayalıdere, G. (2004). Kamu İdaresinde Yönetimden Yönetişime. İktisat İşletme Finans, 19 (220), 56-63. 
Leftwich, A. (1994). Governance, the State and the Politics of Development. Development and Change. 25, 363-386.

Lowndes, V. (2006). Rule, The Encyclopedia of Governance, Mark Bevir (Ed.), Sage.

Löffler, E. (2003). Governance and Government Networking With External Stakeholders. Tony Bovaird and Elke Löffler (Ed.) Public Management and Governance. London: Routledge.

McCormick, J. (2015). Avrupa Birliği Siyaseti. Doğancan Özsel (Çev.). Ankara: Adres.

Peters, B. G. \& Pierre, P. (1998). Governance without Government? Rethinking Public Administration. Journal of Public Administration Research and Theory. 8 (2), 223-243.

Peters, B. G. \& Pierre, J. (2004). Multi-level Governance and Democracy: A Faustian Bargain? Ian Bache \& Matthew Flinders (Ed.). Multi-level Governance (s.75-89). Oxford: Oxford University Press.

Rhodes, R.A.W. (1996). The New Governance: Governing without Government. Political Studies. XLIV, 652-667.

Soyupek, Y. (2012). Avrupa Birliği’nde Karar Verme Mekanizmasının İşleyişi. Özgür Önder ve Fatih Kırışık (Ed.) Kamu Yönetimi ve Siyaset Biliminde Karar Verme (s.557-581). Ankara: Orion.

Stoker, G. (1998). Governance as theory: five propositions. International Social Science Journal. 50, $17-28$.

TODAİE. (1998). Kamu Yönetimi Sözlüğ̈̈, Ankara: TODAİE.

The Legatum Prosperity Index 2015. (2015). London: Legatum Institute.

World Bank. (1992). Governance and Development. Washington: World Bank.

World Bank. (1989). Sub-Saharan Africa: From Crisis to Sustainable Growth. Washington: World Bank.

World Bank. (1994). Governance: The World's Bank's Experience. Washington: World Bank.

World Bank. (1997). World Development Report 1997: The State in a Changing World. New York: Oxford University Press.

Zabcı, F. Ç. (2002). Dünya Bankasının Küresel Pazar İçin Yeni Stratejisi: Yönetişim. Ankara Üniversitesi SBF Dergisi. 57 (3), 151-180.

\section{SUMMARY}

After 1980's the governance concept used intensively has become one of the most popular concepts of social sciences. Especially, it was shown as a solution to the crisis management by the World Bank for developing countries. However, in the same period, this concept was seen as a way out for the crisis paradigmatic of social sciences. In this way the concept of governance in the social sciences has become a popular concept in many areas.

In the World Bank report, governance has been shown as the essential element for economic development and prosperity together with the rule of law and democracy. The report prepared and announced by the World Bank in 1989 titled "Sub-Saharan Africa: From Crisis to Sustainable Growth" has emphasized the refocusing requirements the relations between state and society and stated be downsized the role of state (World Bank, 1989). In the report in 1992, World Bank drew attention to the role of the state in the process of use of authority and forming public policy and has questioned the public administration and focused on the requirements of the new public management approach (World Bank, 1992).

The World Bank report in 1994 emphasized the participation mentioned the development of civil society and the importance of participation of the consumer in decision-making (World Bank, 1994). In its report in 1997, highlighted 
the requirements to develop the capacity to adapt to technological change and to respond to the requirements of the global economy. To increase capacity first revealed deficiencies it should be determined the capacity and then it should be increase the capacity (World Bank, 1997).

In this study, I have attempted to explain the relation between governance and education, health, economics, and personal freedom. I conducted secondary data analysis using data prepared by the Legatum Prosperity Index. There are 142 countries in this index, of governance's ranking of countries is making criteria such as management stability, government effectiveness, rule of law, separation of powers, political rights, confidence to the judicial system, to the army and integrity of election (The Legatum Prosperity Index, 2015).

The aim of the study is to determine the impact of education, health, economy and personal freedom on the governance. Using qualitative and quantitative data, the study has revealed a descriptive and subtractive research. Several tests were applied to analyze statistically the relation between governance and education, health, economy and personal freedom.

142 countries in the data set is divided into five regions, including of the Sub-Saharan Africa, Asia Pacific, Europe, Middle East and America. There are 34 countries in sub-Saharan Africa region where account 23,9\% of the total number of countries in the index. There are 26 countries in the Asia-Pacific region, and it comes to the number $18,3 \%$ of the total number. Most data in the index are from countries in the European region. 43 countries takes place in the index and this number is $30,3 \%$ of total rate. At least there are the countries from the Middle East. 15 countries constitutes 10,6 \% in the total number. In the Americas region, 24 countries constitute $16.9 \%$ of the total number.

As a result of the study, the relation between governance and education are absent, health, economy and personal freedom have been identified a positive relation with the governance. When a country's health, economic and personal freedom scores increased governance score too increase, it reveals that quality of governance due to variables such as health, economy and personal freedom. In 142 countries, when health, economic and personal freedom scores is high the governance score is high too, it reveals that the way of improve the quality of governance is improve the quality of these area. 